\title{
補剛箱形断面偏心圧縮柱の強度に関する実験的研究 \\ EXPERIMENTAL STUDY ON ECCENTRICALLY LOADED STIFFENED BOX COLUMNS
}

\author{
宇佐美 勉*・福 本 唀士**・青木徹彦***・松川昭夫**** \\ By Tsutomu USAMI, Yuhshi FUKUMOTO, Tetsuhiko AOKI and Akio MATSUKA WA
}

\begin{abstract}
An experimental study is presented on the local and overall interaction strength of welded box columns stiffened by longitudinal ribs and diaphragms. The column crosssections are composed of plates with relatively large width-thickness ratios so that local plate buckling is supposed to occur before the attainment of the overall column buckling. The test program consists of (1) six eccentrically loaded column tests, (2) four centrally loaded stub-column tests, and (3) two residual stress measurement tests. Based on the test results, an empirical design formula is proposed to predict the interaction strength.
\end{abstract}

\section{1. 緒言}

長大吊橋・斜張橋主塔には縦リブとダイヤフラムで補 剤された箱形断面部材が通常使用される.このような圧 縮部材の設計は, 従来, 断面の局部座屈が全体座屈に先 行しないことを前提に行われてきた。しかし，ここ10 年来の国の内外の研究により, 通常の断面構成では局部 座屈の発生は不可避であり，圧縮部材の設計にはその影 響を考虑に入れるべきことが判明した ${ }^{1122} .1980$ 年改訂 の道路橋示方書 ${ }^{3)}$ では上記の考え方が取り入れられ，局 部座屈を考慮した圧縮部材の全体座屈強度の評価式が採 用されている.しかし，その評価式は経験式であり，し かも，その妥当性を検討できる実験データは著者らが 行った 3 体の中心軸圧縮柱の実験 ${ }^{4)}$ のみである.

著者らはここ数年来, 無補剛箱形断面部材の局部座屈 と全体座屈の連成強度に関する実験的・理論的研究を行 い, 設計式の提案を行ってきだ)-6). 本研究はそれら一 連の研究の延長として縦リブおよびダイヤフラムで補剛 された箱形断面偏心圧縮柱の強度実験を実施し, 設計式

\footnotetext{
* 正会員 工博 名古屋大学助教授 工学部土木工学科 ( ₹464 名古屋市千種区不老町)

** 正会員 工博 名古屋大学教授 工学部土木工学科(同上)

*** 正会員 工博 要知工業大学助教授 土木工学科

**** 正会員 大阪市土木局土木部橋梁課長
}

の提案を行おうとするものである.

\section{2. 実 験 概 要}

\section{（1）実験供試体}

実験は Fig. 1 および Table 1〜3に示すような 10 体 の供試体の耐荷力実験および 2 体の供試体の残留応力測 定よりなる．使用鋼材は文献 4)で述べた理由により 4.5 $\mathrm{mm}$ 厚の SM 58 材を用いた。ただし，リブの一部には $6 \mathrm{~mm}$ 厚の SM 58 材を用いた。 供試体 1 ～ 8 はフラン ジリブ 2 本, ウェブリブ 1 本の長方形断面（断面高さ／ 幅 $=2 / 3$ ), No. 9, 10 はフランジ, ウェブともリブ 2 本 の正方形断面である. No. 1〜6 は偏心圧縮長柱, No.7 ～10 は中心軸圧縮短柱であり, 細長比 $(L / r)$ は 55,45 , 10 (短柱) と変化させてある. 補剛材間幅厚比は使用鋼 材 SM 58 材の限界幅厚比 ${ }^{3)}$ (全断面降伏荷重に達するま で局部座屈を起こさないと考えられる幅厚比） 22 と, 他に 30 を用いた．長柱の偏心量は弱軸に関する断面 2 次半径 $r$ を基準に， $0.1 r \sim 0.7 r$ まで変化させた. ダ イヤフラム（6 mm 厚の SS 41 材）は両面隅肉溶接（脚 長 $4 \mathrm{~mm}$ ) でフランジ，ウェブに用結した. ダイヤフラ 厶間隔 $L_{0}$ はすべてフランジ幅 $b$ の 1.5 倍である. リブ 材はダイヤフラムを貫通して試験体端部から端部まで連 続しており, 連続溶接（脚長 $4 \mathrm{~mm}$ ) により板に取り付 
けられている.リブの剛性は道路橋示方書 ${ }^{3}$ の縦リブの 必要剛比 $\gamma_{r e q}$ に等しくなるように設計した.

供試体の実測方法およびそれをもとに計算した諸量 は, Table 2, 3 に示してある. 記号の一部は同表および, Fig. 1，Table 1 に定義してある.

\section{（2）素材試験，残留忍力測定，初期たわみ測定}

実験供試体は 4 枚の圧延板より切断・製作された。 そ れぞれの板について 3 本ずつ JIS 5 号試験片を切り出 し材料定数を測定した. 残留応力は供試体 No. 13，14 の 2 体のフランジ， ウェブおよびリブについて切断法に より測定した．構成板の面外初期たわみはすべての供試 体中央のフランジパネル(ダイヤフラムおよびフランジウェブ接合線で囲まれたパネル）について最小目盛 1／
$500 \mathrm{~mm}$ ダイヤルゲージにより測定した。測定はフラン ジーウェブ接合線を基準にした板の面外変位をまず測定 し，次にフランジーウェブ接合線とダイヤフラムの交点 を基準にした接合線の面外変位を測定し，先に測定した 板の変位の基準線を補正して板パネルの実面外変位を決 定した。柱軸線の初期たわみは偏心圧縮柱ではその影響 が小さいと考えられるため測定は行わなかった。

\section{（3）短柱実験}

短柱試験（No.7～10）はすべて平押し圧縮によって 行った。短柱中央の載荷軸ひずみを測定するとともに, 断面の 4 隅にセットしたダイヤルゲージにより中央パネ ルの軸方向縮み (ダイヤフラム位置の相対的荷重方向变 位)を測定した。用いた試験機は建築技術研究所(吹田市)
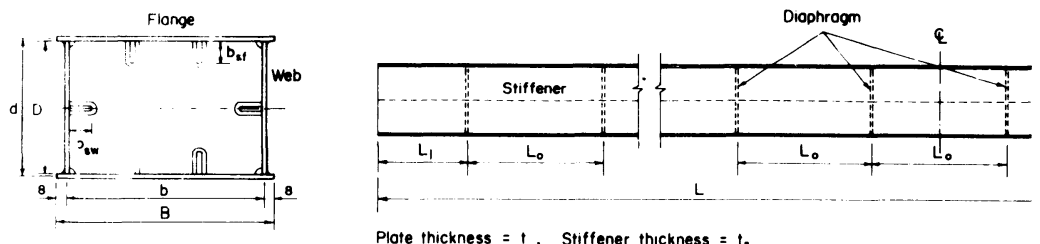

(a) Test Specimen Nos. 1 8
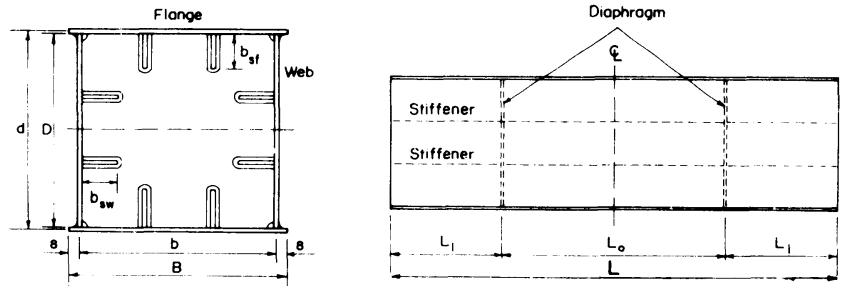

(b) Test Specimen Nos. 9 and 10

Fig.1 Test Specimen.

Table 1 Test Program.

\begin{tabular}{|c|c|c|c|c|c|c|c|c|c|}
\hline Specimen & $\mathrm{L} / \mathrm{r}$ & $\mathrm{n}_{\mathrm{f}}$ & $\mathrm{n}_{\mathrm{w}}$ & $d / b$ & $b /\left(n_{f} t\right)$ & $\mathrm{R}_{\mathrm{f}}$ & $\mathrm{L}_{0} / \mathrm{b}$ & $e / x$ & Remarks \\
\hline 1 & 55 & 3 & 2 & 0.667 & 22 & 0.6 & 1.50 & 0.1 & \multirow{6}{*}{$\begin{array}{l}\text { Eccentrically } \\
\text { Loaded Column } \\
\text { Tests }\end{array}$} \\
\hline 2 & 45 & 3 & 2 & 0.667 & 30 & 0.8 & 1.50 & 0.2 & \\
\hline 3 & 55 & 3 & 2 & 0.667 & 22 & 0.6 & 1.50 & 0.3 & \\
\hline 4 & 45 & 3 & 2 & 0.667 & 30 & 0.8 & 1.50 & 0.5 & \\
\hline 5 & 55 & 3 & 2 & 0.667 & 22 & 0.6 & 1.50 & 0.6 & \\
\hline 6 & 45 & 3 & 2 & 0.667 & 30 & 0.8 & 1.50 & 0.7 & \\
\hline 7 & 10 & 3 & 2 & 0.667 & 22 & 0.6 & 1.50 & 0 & \multirow{4}{*}{$\begin{array}{l}\text { Stub-Column } \\
\text { Tests }\end{array}$} \\
\hline 8 & 10 & 3 & 2 & 0.667 & 30 & 0.8 & 1.50 & 0 & \\
\hline 9 & 7.4 & 4 & 4 & 1.0 & 22 & 0.6 & 1.50 & 0 & \\
\hline 10 & 7.4 & 4 & 4 & 1.0 & 30 & 0.8 & 1.50 & 0 & \\
\hline 13 & - & 3 & 2 & 0.667 & 22 & 0.6 & - & - & Residual.Stress \\
\hline 14 & - & 3 & 2 & 0.667 & 30 & 0.8 & - & - & Measurements \\
\hline & \multicolumn{9}{|c|}{$\begin{array}{l}\text { 1. See Fig. } 1 \text { for symbols } b, d, t, L \text {, and } L_{0} \text {. } \\
\text { 2. } r=\text { radius of gyration about the weak axis, } n_{f}=\text { no. of } \\
\text { subpanels in flange, } n_{w}=\text { no. of subpanels in web, e }=\text { ec- } \\
\text { centricity of load, and } R_{f}=\text { Eq. } 2 \text { with } k=4 n_{f}^{2}, \sigma_{y}=540 \\
N / \mathrm{mm}^{2} \text { and } E=206000 \mathrm{~N} / \mathrm{mm}^{2} \text {. }\end{array}$} \\
\hline
\end{tabular}


の1000 t 長柱武験機である. 整置 (alignment) および 載荷方法はおおむね文献 7 ) に従った。

\section{(4) 長柱試験}

長柱試験はすべて両端ピン支持の条件で行った。ピン 支持装置は文献 4)，5）で使用した装置を参考により大 型化した装置を製作し使用した。載荷要領は文献 5$)$ と 同様であるのでここでは省略する，偏心圧縮荷重は荷重 を強軸上に偏心させて行った。用いた武験機は愛知工業 大学の $300 \mathrm{t}$ 長柱試験機である.

\section{3. 実験結果および考察}

\section{（1）秦材試験}

引張試験から得られた素材の応力ーひずみ関係はひず みが $1 \%$ 以内ではひずみ硬化が現われず，ほぼ普通鋼と 同様の応力ーひずみ関係が得られた，測定された各供試
体の板要素降伏応力 $\sigma_{y}$ および補剛材の降伏応力 $\sigma_{y s}$ の 值を Table 2 に示す. 弾性係数 $E$ は各供試体で大差な くその平均值は $2.10 \times 10^{5} \mathrm{~N} / \mathrm{mm}^{2}$ であった。これらの 值を用いて計算した各供試体の等価細長比 $\bar{\lambda}$, フランジ 板の等価幅厚比 $R$ を Table 2 に示す.ここに,

$$
\begin{aligned}
& \bar{\lambda}=\frac{L}{r} \frac{1}{\pi} \sqrt{\frac{\bar{\sigma}_{y}}{E}} \ldots \ldots \ldots \ldots . . \\
& R=\frac{b}{t} \sqrt{\frac{\bar{\sigma}_{y}}{E} \frac{12\left(1-\nu^{2}\right)}{\pi^{2} k}} .
\end{aligned}
$$

である。上式中, $L$ は部材全長, $t$ はフランジ板厚, $\bar{\sigma}_{y}$ は板要素とりブの断面積で重みをつけた平均降伏応力を 表わす。またンはポアソン比で 0.3 を用いた. $k$ はフ ランジ板要素の座屈係数で, Table 2 には 2 種類の $k$ か ら求められた $R$ の值が記載されている. 1 つは $k=4 n_{f}^{2}$ (ここに， $n_{f}$ はフランジのサブパネル数) に対する $R$

\begin{tabular}{|c|c|c|c|c|c|c|c|c|c|c|c|c|c|c|c|c|c|c|}
\hline $\begin{array}{l}\text { Speci- } \\
\text { men }\end{array}$ & $\mathrm{mm}$ & $\mathrm{mm}$ & $\mathrm{mm}$ & $b_{\text {sf }}$ & $b_{\text {sw }}$ & $t_{s}$ & $\begin{array}{c}\mathrm{O}_{\mathrm{y}} \\
\mathrm{N} / \mathrm{mm}^{2}\end{array}$ & $\begin{array}{c}\sigma_{\mathrm{ys}} \\
\mathrm{N} / \mathrm{mm}^{2}\end{array}$ & $\begin{array}{c}\bar{\sigma}_{\mathrm{y}} \\
\mathrm{N} / \mathrm{mm}^{2}\end{array}$ & $\mathrm{~mm}^{2}$ & $\mathrm{~mm}^{3}$ & $\mathrm{~mm}$ & $\mathrm{~mm}$ & $\mathrm{~L} / \mathrm{r}$ & $\bar{\lambda}$ & $\frac{b}{n_{f} t}$ & $\begin{array}{c}\mathrm{R} \\
\text { with } \\
\mathrm{k}=4 \mathrm{n}_{\mathrm{f}}^{2}\end{array}$ & $\begin{array}{c}R \\
\text { with } \\
k=k_{\text {eq }}\end{array}$ \\
\hline 1 & 316 & 196 & 4.44 & 9.1 & 34.3 & 4.51 & 479 & 479 & 479 & 5560 & 57300 & 4800 & 82.9 & 57.9 & 0.870 & 22.5 & 0.559 & 0.542 \\
\hline 2 & 436 & 281 & 4.48 & 42.6 & 37.6 & 4.51 & 527 & 527 & 52 & & 73900 & 5200 & 119.0 & 43.7 & 0.699 & 31.2 & 0.829 & 0.814 \\
\hline 3 & 317 & 196 & 4.46 & 39.7 & 34.8 & 4.48 & 479 & 479 & 479 & 5600 & 37500 & 4800 & 82.9 & 57.8 & 0.870 & 22.5 & 0.558 & 0.541 \\
\hline 4 & 436 & 266 & 4.49 & 42.5 & 37.5 & 4.52 & 527 & 527 & 527 & 7410 & 69400 & 5200 & 113.0 & 46.0 & 0.735 & 31.2 & 0.826 & 0.798 \\
\hline 5 & 317 & 196 & 4.42 & 39.3 & 34.7 & 4.41 & 527 & 527 & 527 & 5530 & 37100 & 4800 & 82.9 & 57.8 & 0.929 & 22.7 & 0.610 & 0.584 \\
\hline 6 & 437 & 281 & 4.57 & 42.1 & 37.9 & 4.56 & 527 & 527 & 527 & 7690 & 75500 & 5200 & 119.0 & 43.7 & 0.699 & 30.7 & 0.814 & 0.799 \\
\hline 7 & 317 & 196 & 4.43 & 39.6 & 34.2 & 4.33 & 552 & 552 & 552 & 5530 & 37200 & 900 & 83.0 & 10.8 & 0.090 & 22.6 & 0.617 & $0 . \overline{598}$ \\
\hline 8 & 422 & 267 & 4.57 & 42.2 & 37.3 & 4.49 & 552 & 552 & 552 & 7390 & 69000 & 1200 & 114.0 & 10.5 & 0.087 & 29.6 & 0.807 & 0.789 \\
\hline 9 & 417 & 397 & 4.58 & 45.5 & 45.5 & 6.02 & 552 & 525 & 544 & 10700 & 124000 & 1200 & 153.0 & 7.8 & 0.064 & 21.9 & 0.592 & 0.592 \\
\hline 10 & 557 & 537 & 4.55 & 49.4 & 49.4 & 5.96 & 552 & 525 & 546 & 13500 & 218000 & 1620 & 210.0 & 7.7 & 0.063 & 29.7 & 0.805 & 0.805 \\
\hline 13 & 316 & 196 & 4.50 & 39.0 & 34.0 & 4.50 & 527 & 527 & 527 & - & - & 1000 & - & - & - & 22.0 & 0.582 & 0.566 \\
\hline 14 & 421 & 266 & 4.50 & 42.0 & 37.0 & 4.50 & 552 & 552 & 552 & - & - & 1000 & - & - & - & 30.0 & 0.818 & 0.800 \\
\hline
\end{tabular}

Table 2 Dimensions of Test Specimens.

Note: 1 . See Fig. 1 for symbols $B, D, t, b_{s f}, b_{s w}, t_{s}$ and $L$.

2. $\sigma_{y}=$ yield stress of plate; $\sigma_{y s}=$ yield stress of stiffeners; $\bar{\sigma}_{y}=$ weighted average of yield stresses;

$A=$ cross-sectional area; $W=$ elastic section modulus about the weak axis; $\bar{\lambda}=\mathrm{Eq} \cdot 1 ; \mathrm{K}=\mathrm{Eq} \cdot 2 ;$

$\mathrm{k}_{\text {eq }}=$ equivalent buckling coefficient (Eq. A.1)

\begin{tabular}{|c|c|c|c|c|c|c|c|c|c|c|c|c|}
\hline \multirow[t]{2}{*}{ Specimen } & \multicolumn{6}{|c|}{ Flange Stiffener } & \multicolumn{6}{|c|}{ Web Stiffener } \\
\hline & Area $A_{\text {sf }}$ & $\begin{array}{l}\text { Moment of } \\
\text { Inertia } \mathrm{I}_{\mathrm{sf}} \\
\mathrm{mm}\end{array}$ & $\delta_{\mathrm{f}}$ & $Y_{f}$ & $\gamma_{f, r e q}$ & $\frac{\gamma_{f}}{\gamma_{f, r e q}}$ & $\begin{array}{c}\text { Area } A_{\mathrm{sw}} \\
\mathrm{mm}\end{array}$ & $\begin{array}{l}\text { Moment of } \\
\text { Inertia I sw } \\
\mathrm{mm}\end{array}$ & $\delta_{w}$ & $\gamma_{w}$ & $\gamma_{w}, r e q$ & $\frac{\gamma_{w}}{\gamma_{w, r e q}}$ \\
\hline 1 & 176 & 89900 & 0.132 & 37.4 & 34.2 & 1.09 & 155 & 60700 & 0.174 & 37.9 & 36.2 & 1.05 \\
\hline 2 & 192 & 116000 & 0.102 & 33.5 & 31.7 & 1.06 & 170 & 79900 & 0.133 & 34.0 & 32.9 & 1.03 \\
\hline 3 & 179 & 93400 & $0.133 !$ & 38.2 & 34.3 & 1.11 & 156 & 62900 & $0.175 \mid$ & 38.7 & 36.3 & 1.07 \\
\hline 4 & 1.92 & 116000 & 0.102 & 33.3 & 31.7 & 1.05 & 170 & 79500 & 0.140 & 35.5 & 33.4 & 1.06 \\
\hline 5 & 173 & 89200 & 0.130 & 37.5 & 34.0 & 1.10 & 153 & 61400 & 0.173 & 38.8 & 36.1 & 1.07 \\
\hline 6 & 194 & 118000 & 0.101 & 32.1 & 31.7 & 1.01 & 173 & 82700 & 0.132 & 33.1 & 32.8 & 1.01 \\
\hline 7 & 171 & 89600 & 0.128 & 37.4 & 33.8 & 1.11 & 148 & 57700 & 0.167 & 36.2 & 35.6 & 1.02 \\
\hline 8 & 189 & 112000 & 0.102 & 31.6 & 31.7 & 1.00 & 167 & 77700 & 0.134 & 32.7 & 33.0 & 0.99 \\
\hline 9 & 274 & 189000 & 0.149 & 53.8 & 54.8 & 0.98 & 274 & 189000 & 0.149 & 53.6 & 54.8 & 0.98 \\
\hline .10 & 294 & 240000 & 0.119 & 51.4 & 50.5 & 1.02 & 294 & 240000 & 0.119 & 51.4 & 50.5 & 1.02 \\
\hline
\end{tabular}

Table 3 Stiffener Properties.

Notes: $I_{s f}=t_{s} b_{s f}^{3} / 3 ; I_{s w}=t_{s} b_{s w}^{3} / 3 ; \quad \delta_{f}=A_{s t} / b t ; \quad \delta_{w}=A_{s w} / d t ; \quad \gamma_{f}=E I_{s f} / b K ; \quad \gamma_{w}=E I_{s w} / d K ;$

$\mathrm{K}=\mathrm{Et} \mathrm{t}^{3} / 12\left(1-\nu^{2}\right) ; \quad \gamma_{\mathrm{f}, \text { req }}=4\left(\mathrm{~L}_{0} / \mathrm{b}\right)^{2} \mathrm{n}_{\mathrm{f}}\left(1+\mathrm{n}_{\mathrm{f}} \delta_{\mathrm{f}}\right)-\left(1+\mathrm{L}_{0}^{2} / \mathrm{b}^{2}\right)^{2} / \mathrm{n}_{\mathrm{f}} ; \quad \gamma_{\mathrm{w}, \text { req }}=4\left(\mathrm{~L}_{0} / \mathrm{d}\right)^{2} \mathrm{n}_{\mathrm{w}}\left(1+\mathrm{n}_{\mathrm{w}} \delta_{\mathrm{w}}\right)$

$-\left(1+L_{0}^{2} / d^{2}\right)^{2} / n_{w}$. 
であり，他は $k=k_{e q}$ に対する $R$ である. $k_{e q}$ は文献 4$)$ ， 5 )で等価座屈係数と称した量で, 長方形箱形断面の圧縮 強度をフランジ幅が同一の正方形箱形断面の圧縮強度に 換算するために導入された量である． $k_{e q}$ の具体的な式 は付録( 1 )に示してある.

\section{( 2 )残留応力}

残留応力は供試体 No.13，14 のフランジ，ウェブ各 1 枚およびそれらのリブについて測定を行った。板要素 の平均圧縮残留応力 $\sigma_{r c}$ は No. 13 (補剛材間幅厚比 $=22$ ) で $200 \sim 250 \mathrm{~N} / \mathrm{mm}^{2}\left(\sigma_{r c} / \sigma_{y}=0.38 \sim 0.47\right)$, No. 14 (補 剛材間幅厚比 $=30)$ で $150 \sim 200 \mathrm{~N} / \mathrm{mm}^{2} \quad\left(\sigma_{r c} / \sigma_{y}=0.27\right.$ ～0.36）程度である. 一方，リブの最大圧縮残留応力の 各供試体平均值は, No. 13 で $230 \mathrm{~N} / \mathrm{mm}^{2}\left(\sigma_{r c} / \sigma_{y s}\right.$ $=0.44)$, No. 14 で $200 \mathrm{~N} / \mathrm{mm}^{2}\left(\sigma_{r c} / \sigma_{y s}=0.36\right)$ 程度で あった。なお，残留応力の分布形などの全測定デー夕は 文献 8) に含まれている。

\section{（3）初期面外たわみ}

柱中央パネルの初期面外たわみは，偏心圧縮性につい ては最圧縮側フランジ，短柱については両フランジで測 定した。板の耐荷力にとって重要な量はダイヤフラムの 位置を基準とした初期たわみ量であるので，测定結果か ら，フランジーウェブ接合線に平行でダイヤフラムの位 置での初期たわみを結んだ基線から板および補剛材の初 期たわみを測り直し，その最大值を求めたものが Table 4 の值である．表中，負のたわみは供試体内側，正のた わみは外側へのたわみを表わす。1 例を除き，最大初期 たわみは補剛材のある方向に生じていることがわかる. 板の初期たわみは, $b / 500$ 前後と小さいが, 補剛材の初 期たわみは $L_{0} / 1000$ を越える供試体が多くあることが わかる.なお，全供試体の初期たわみ形状のデー夕は文

Table 4 Maximum Plate and Stiffener Initial Deflections.

\begin{tabular}{|c|c|c|c|c|c|c|}
\hline Specimen & $\mathrm{mm}$ & $\begin{array}{l}\mathrm{L}_{0} \\
\mathrm{~mm}\end{array}$ & $\begin{array}{l}{ }_{p}{ }_{p} \\
m_{n}\end{array}$ & $\begin{array}{l}\mathrm{w}_{\mathrm{s}} \\
\mathrm{mm}\end{array}$ & $w_{p} / b$ & $\mathrm{w}_{\mathrm{s}} / \mathrm{L}_{0}$ \\
\hline 1 & 300 & 450 & -0.65 & -0.65 & $-1 / 460$ & $-1 / 690$ \\
\hline 2 & 405 & 600 & -0.65 & -0.55 & $-1 / 620$ & $-1 / 1090$ \\
\hline 3 & 300 & 450 & -0.75 & -0.75 & $-1 / 400$ & $-1 / 600$ \\
\hline 4 & 405 & 600 & -0.50 & -0.50 & $-1 / 810$ & $-1 / 1200$ \\
\hline 5 & 300 & 450 & -0.65 & -0.65 & $-1 / 460$ & $-1 / 690$ \\
\hline 6 & 405 & 600 & -0.95 & -0.50 & $-1 / 430$ & $-1 / 1200$ \\
\hline $7(\mathrm{~A})$ & 300 & 450 & -0.60 & -0.60 & $-1 / 500$ & $-1 / 750$ \\
\hline (B) & 300 & 450 & -0.55 & -0.55 & $-1 / 550$ & $-1 / 820$ \\
\hline 8 (A) & 405 & 600 & -0.60 & -0.45 & $-1 / 680$ & $-1 / 1330$ \\
\hline (B) & 405 & 600 & -0.70 & -0.70 & $-1 / 580$ & $-1 / 860$ \\
\hline (A) & 400 & 600 & +1.20 & +1.10 & $+1 / 330$ & $+1 / 550$ \\
\hline (B) & 400 & 600 & -0.55 & -0.55 & $-1 / 730$ & $-1 / 1090$ \\
\hline 10 (A) & 540 & 810 & -0.60 & -0.55 & $-1 / 900$ & $-1 / 1470$ \\
\hline (B) & 540 & 810 & -0.90 & -0.90 & $-1 / 600$ & $-1 / 900$ \\
\hline
\end{tabular}

Notes: 1. Positive deflection is the deflection toward the inside of specimen.

2. $w_{p}=$ maximum plate deflection; $w_{s}=$ maximum stiffener deflection.
献 8) に示されている

\section{(4) 短柱}

Fig. 2 は中央パネルの軸方向縮みをダイヤフラム間隔 $\left(L_{0}\right)$ で除して求めた平均ひずみ $\left(\varepsilon_{a}\right)$ を荷重 $(P)$ に対して プロットしたものである.ただし, 縦軸, 横軸はそれぞれ, 全断面降伏荷重 $P_{y}=\bar{\sigma}_{y} A$ (ここに $A$ は全断面積)，平均 降伏ひずみ $\bar{\varepsilon}_{y}=\bar{\sigma}_{y} / E$ で無次元化してある．細線は弾性 理論から求められた理論直線である．荷重が小さい間は No. 7 供試体を除き弾性理論とよく一致しているが，荷 重が大きくなると，断面の局部座屈，塑性化の影響によ り理論值と離れてゆく. No. 7 供試体は載荷の途中から 断面の対角線方向に偏心載荷された状態になったため, 理論曲線と一致しなかったものと思われる. 事実，この 供試体のみ，ウェブ板の局部座屈が先行して生じた状態 で崩壊に至っている.

実験から得られた最高荷重 $P_{\max }, P_{\max } / P_{y}$ を Table 5 に示し， $P_{\max } / P_{y}$ を等価幅厚比 $R$ （ただし，正方形断 面に対しては $k=4 n_{f}^{2}$, 長方形断面に対しては $\left.k=k_{e q}\right)$ に対してプロットしたものを Fig. 3 に示す. 同図中には 文献 4) の実験結果もプロットしてある. また，同図中 の直線式

$$
\frac{P_{\max }}{P_{y}}=1.24-0.54 R
$$

は補剛材剛比が現行道路橋示方書の縦方向補剛材必要剛 比の $0.6 \sim 2.0$ 倍にある補剛材つき板の実験結果を最小

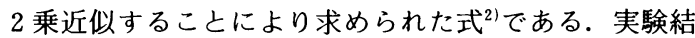
果と式( 3 )を比べると, 1 例(No. 7 ) を除き, 式( 3 ) は実験のほぼ下界の直線になっていることがわかる。 No. 7 供試体の強度のみ式（3)を下まわっているが，こ れは前述のように偏心載荷の影響であろうと思われる.

\section{（5）長柱}

偏心圧縮長柱の荷重-柱中央のたわみ $(\delta)$ の実験値を 局部座屈を考慮しない弾性理論解析（はり一柱理論）結 果とともに Fig. 4 に示す. $L / r=45$ の柱の $R_{f}(k=4$ $n_{f}^{2}$ のときの $R$ ) は $0.8, L / r=55$ の柱の $R_{f}$ は 0.6 で ある. 荷重の小さい間は全般的に実験值は弾性理論とよ く一致している. 荷重が大きくなると, 局部座屈と塑性 の影響により，実験值は理論解と離れてゆく，一般的に 全ケースとも変形能はかなり大きいと思われる.

Fig. 5 は柱中央最圧縮フランジ上で測定した軸方向ひ ずみ $\varepsilon の$ 荷重による変化を描いたものである。これら の図よりフランジ板の変形モードを推察することが可能 である. フランジーウェブ接合線上の 2 点の各荷重段階 でのひずみはほぼ一致しており，それらのひずみを結ん だ線の上方に他点のひずみがある場合にはフランジ板は 断面内側に変形（凹む）し，下方にあるときは外側に変 形 (凸む) ことがわかる. 変形モードは無補剛板の場合 ${ }^{5}$ 


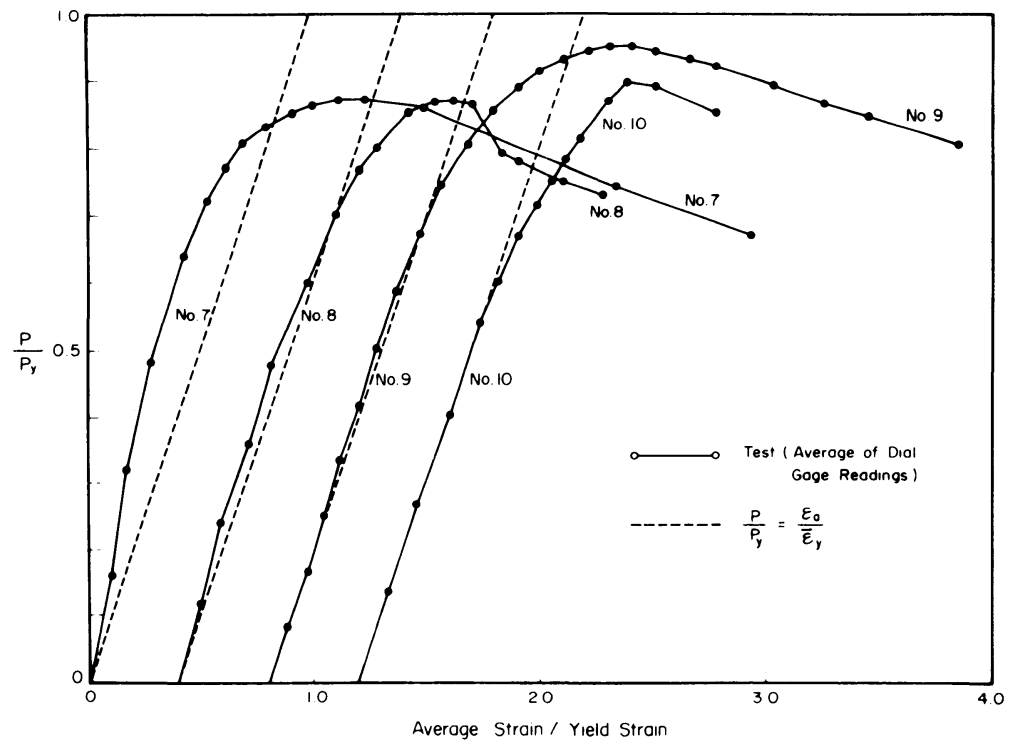

Fig. 2 Average Stress-Strain Curves of Stub-Columns.

より複雑であり，フランジ板全体の半波長形モードと， 補剛材間および補剛材とウェブ間の変形モードが組み合 わさったものとなっている. 偏心量の小さいNo.1 と No. 2 の供試体では最高荷重はほぼフランジーウェブ接 合線上のひずみが降伏ひずみ（図中に $\varepsilon_{y}$ と表示）に一 致したときに生ずるが, 偏心量が大きくなると, 最高荷 重は接合線上のひずみが $\varepsilon_{y}$ をかなり越えた状態で生じ ている．これは前報 4) の曲げ試験でも観察されたこと であり, 有効幅理論で通常用いられる仮定すなわち縁応 力が降伏応力に達したときに板要素は崩壊するという仮 定は, 偏心量の大きい供試体のように, 各構成板要素の 強度に大きく差がある断面構成, 荷重状態の場合はかな

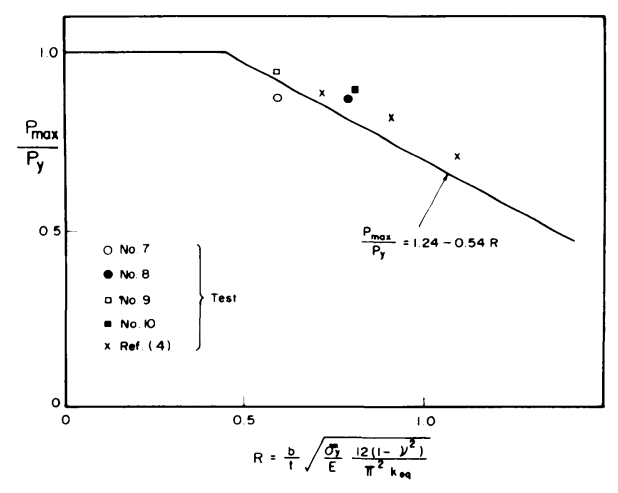

Fig. 3 Maximum Strength of Stub-Columns.

Table 5 Comparison of Experimental and Predicted Maximum Loads.

\begin{tabular}{|c|c|c|c|c|c|c|c|}
\hline \multirow[t]{3}{*}{ Specimen } & \multicolumn{3}{|c|}{ Experimental } & \multirow{2}{*}{\multicolumn{2}{|c|}{\begin{tabular}{|c|} 
Predicted \\
$\left(\frac{\mathrm{P}_{\max }}{\mathrm{P}_{\mathrm{y}}}\right)$ appr \\
\end{tabular}}} & \multirow{2}{*}{\multicolumn{2}{|c|}{$\frac{\left(\mathrm{P}_{\max } / \mathrm{P}_{\mathrm{y}}\right) \exp }{\left(\mathrm{P}_{\max } / \mathrm{P}_{\mathrm{y}}\right)}$}} \\
\hline & \multirow{2}{*}{$\begin{array}{l}\mathrm{P}_{\max } \\
\text { in } \\
\mathrm{kN}\end{array}$} & \multirow{2}{*}{$\begin{array}{l}P_{y} \\
\text { in } \\
k N\end{array}$} & \multirow[t]{2}{*}{$\left(\frac{{ }^{\text {max }}}{P_{y}}\right) \exp$} & & & & \\
\hline & & & & $\begin{array}{lll}\text { SSRC } 2 & \end{array}$ & JRA & SSRC 2 & JRA \\
\hline 1 & 1620 & 2650 & 0.611 & 0.582 & 0.542 & 1.05 & 1.13 \\
\hline 2 & 2020 & 3970 & 0.509 & 0.531 & 0.501 & 0.959 & 1.02 \\
\hline 3 & 1380 & 2670 & 0.517 & 0.480 & 0.454 & 1.07 & 1.13 \\
\hline 4 & 1590 & 3910 & 0.407 & 0.415 & 0.395 & 0.981 & 1.03 \\
\hline 5 & 1080 & 2920 & 0.370 & 0.368 & 0.352 & 1.01 & 1.05 \\
\hline 6 & 1450 & 4050 & 0.358 & 0.373 & 0.359 & 0.957 & 0.994 \\
\hline 7 & 2660 & 3050 & 0.872 & 0.911 & 0.911 & 0.956 & 0.956 \\
\hline 8 & 3550 & 4080 & 0.870 & 0.812 & 0.812 & 1.07 & 1.07 \\
\hline 9 & 5550 & 5850 & 0.949 & 0.928 & 0.928 & 1.02 & 1.02 \\
\hline 10 & 6600 & 7360 & 0.896 & 0.814 & 0.814 & 1.10 & 1.10 \\
\hline
\end{tabular}


り安全側の仮定になる.

実験終了後の供試体中央付近の最圧縮フランジの変形 を示す写真をPhoto1 に示す.

実験より得られた最高荷重はTable 5 に示してある. 同表中には文献 4)，5）で提案した近似解法を補剛断面 材に適用できるように修正した解法に基づく近似解 (Predicted) も併せて載せてある. 近似解法は付録(2) に詳述してある。近似解のうち，SSRC 2 は，局部座屈 を考えない柱の強度式として $\mathrm{SSRC}^{91}$ の柱強度曲線の No. 2 曲線を用いたもの，JRA は柱の強度式として現 行道路橋示方書の柱の基準耐荷力式 ${ }^{3)}$ を用いたものであ ることを示す。また，偏心圧縮長柱の強度の推定相関式
(付録( 2 )の式 $(\mathrm{A} \cdot 2)$ ) を実験結果とともに Fig. 6 に示 す.これらの図および表からわかるように，SSRC No. 2 曲線に基づく解は実験值に対して非常によい相関 をもっている．また，道路橋示方書の式に基づく解は， 短柱の一例 (No. 7 供試体) を除き，全般的に安全側の 推定值を与えることがわかる.

\section{4. 設計公式の提案}

文献 4) および本報告の実験結果を踏まえ，幅厚比の 比較的大きい補剛箱形断面圧縮部材の設計式の提案を行 う. 無補剛箱形断面圧縮部材については文献 4) で述へ た。

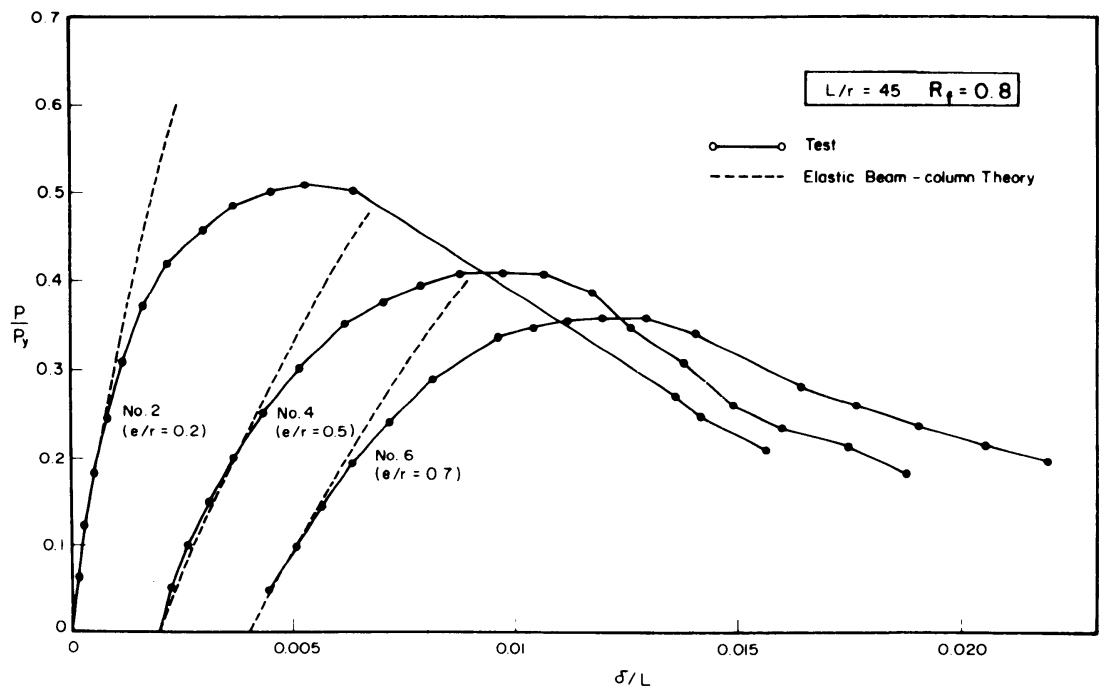

(a) Load-Midheight Deflection Curves (Column Nos. 2, 4 and 6)

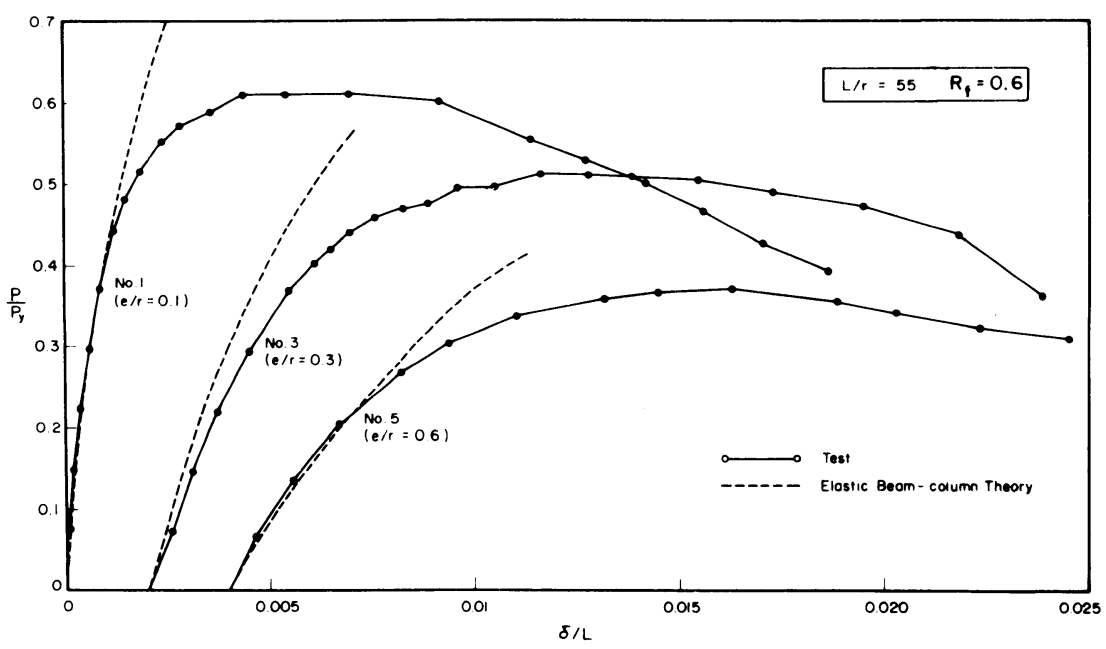

(b) Load-Midheight Deflection Curves (Column Nos. 1, 3 and 5)

Fig. 4 
（1）条件

(1) フランジ幅 $b$, ウェブ幅 $d$, フランジ厚 $t$, ウェ ブ厚 $w$, フランジサブパネル数 $n_{f}$, ウェブサブパ ネル数 $n_{w}$ の等間隔補剖箱形断面を考える.

(2) 補剛材剛度は道路橋示方書の必要剛比以上とす る.

(3) 補剛材幅厚比は道路橋示方書の幅厚比制限以下と する.

（2）設 計 式

(1) 次式により降伏応力の低減係数を求める.

$Q=1.24-0.54 R \leqq 1.0$

ここに, $R$ は次式より求められる $R_{f}$ と $R_{w}$ の大きい値 とする.

$$
\begin{aligned}
& R_{f}=\frac{b}{t} \sqrt{\frac{\bar{\sigma}_{y f}}{E} \frac{12\left(1-\nu^{2}\right)}{\pi^{2} 4 n_{f}^{2}}}=0.526 \frac{b}{t n_{f}} \sqrt{\frac{\bar{\sigma}_{y f}}{E}} \cdots \cdots(5) \\
& R_{w}=\frac{d}{w} \sqrt{\frac{\sigma_{y w}}{E} \frac{12\left(1-\nu^{2}\right)}{\pi^{2} 4 n_{w}^{2}}}=0.526 \frac{d}{w n_{w}} \sqrt{\frac{\sigma_{y w}}{E}} \cdots(6)
\end{aligned}
$$

ここに, $\bar{\sigma}_{y f}$ フランジ補剛板の平均降伏応力（フランジ
板要素およびフランジ補剛材の断面積で重みをつけた平 均降伏応力), $\bar{\sigma}_{y w}=$ ウェブ補剛板の平均降伏応力であ る.

(2) 中心軸圧縮柱の強度 $P_{u}$ は次式より求める.

$$
\begin{aligned}
\frac{P_{u}}{Q P_{y}} & =1.0 \quad\left(\overline{\lambda^{\prime}} \leqq 0.2\right) \\
& =1.109-0.545 \overline{\lambda^{\prime}} \quad\left(0.2 \leqq \bar{\lambda}^{\prime} \leqq 1.0\right) \cdots \\
& =\frac{1}{0.773+\bar{\lambda}^{\prime 2}} \quad\left(1.0 \leqq \bar{\lambda}^{\prime}\right)
\end{aligned}
$$

ここに,

$$
\overline{\lambda^{\prime}}=\sqrt{Q} \bar{\lambda}=\frac{L}{r} \frac{1}{\pi} \sqrt{\frac{Q \bar{\sigma}_{y}}{E}}
$$

で $\bar{\sigma}_{y}$ は断面全体の平均降伏応力, $P_{y}=\bar{\sigma}_{y} A$ は全断面降 伏荷重, $L / r$ は細長比である.

(3) 両端の軸方向圧縮力 $P$ と 1 軸曲げモーメント $M$ を受けるはり一柱は次式を満足するように設計する.

$$
\frac{P}{P_{u}}+\frac{M}{M_{u}\left(1-P / P_{E}\right)} \leqq 1.0
$$
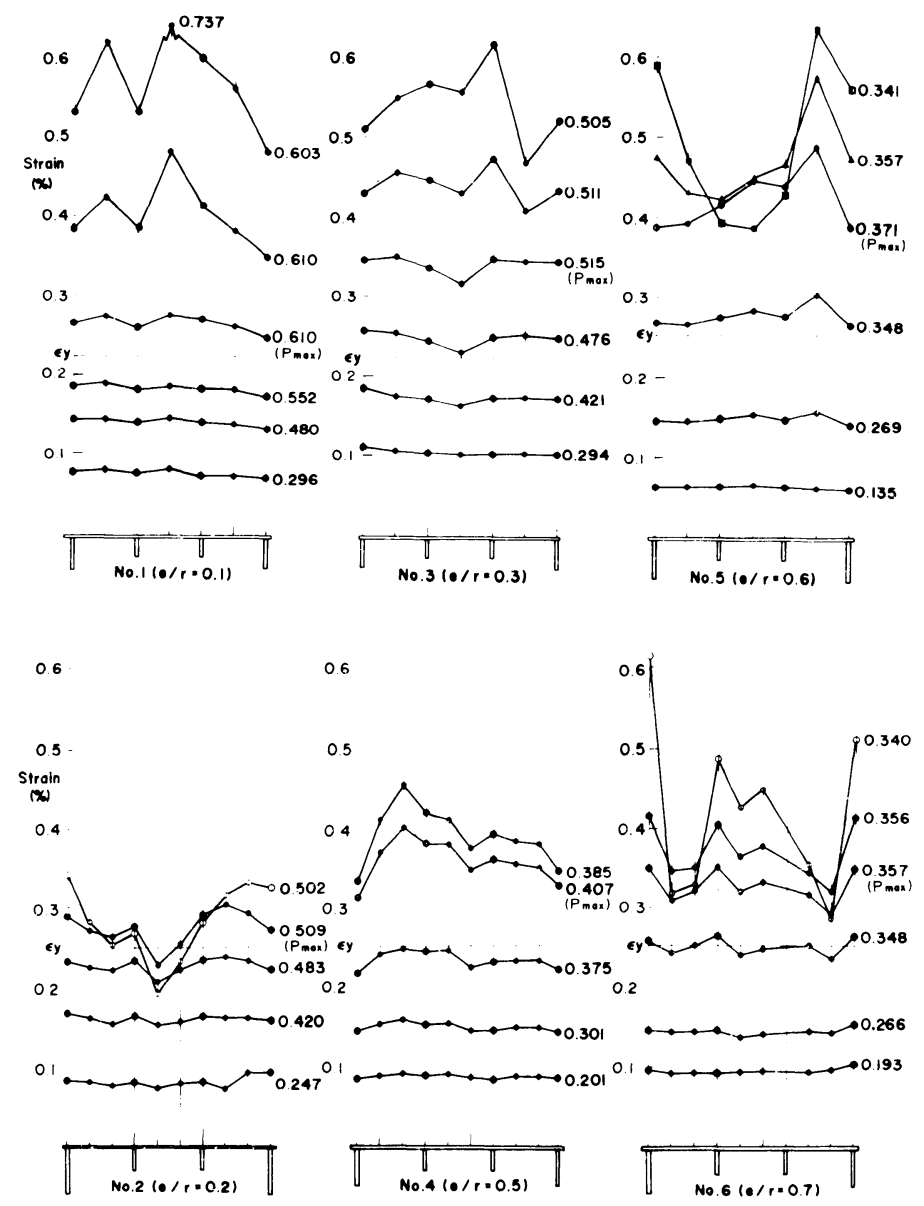

Fig. 5 Strain Variations on the Most Compressed Flange of Midheight Column Cross-section. 


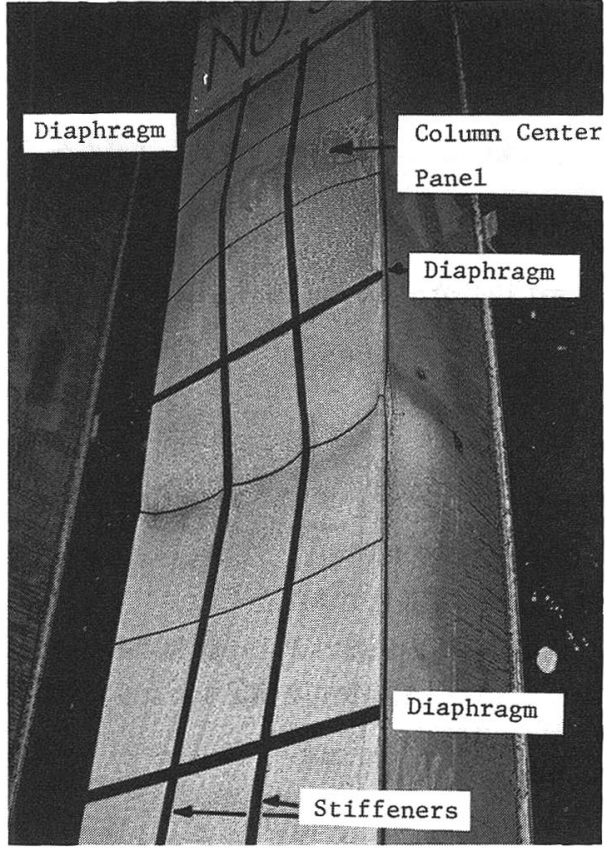

Photo1 Column No. 5 after Failure.

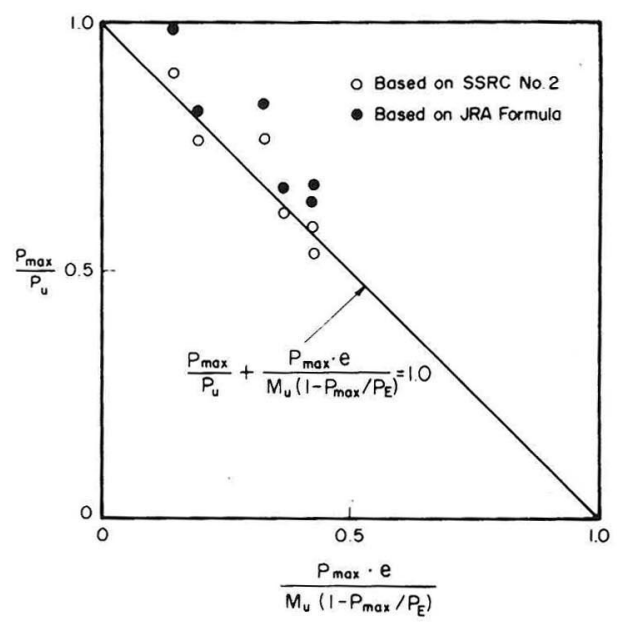

Fig. 6 Comparison of Experimental and Predicted Strength.

$$
\frac{P}{Q P_{y}}+\frac{M}{M_{u}\left(1-P / P_{E}\right)} \leqq 1.0
$$

ここに $P_{E}=$ 座屈軸に関するオイラ一座屈荷重

$$
\begin{aligned}
& \frac{M_{u}}{M_{y}}=\frac{(2+3 / \alpha \beta)\left(1.24-0.54 R_{f}\right)+2+\alpha \beta}{4+\alpha \beta+3 / \alpha \beta} \leqq 1.0 \cdots \\
& M_{y}=W \bar{\sigma}_{y f} \\
& W=\text { 座屈軸に関する弾性断面係数 } \\
& \alpha \beta=\frac{d \cdot w}{b \cdot t}
\end{aligned}
$$

なお，部材両端に不等曲げモーメント $M$ および $x M(-1 \leqq x \leqq 1)$ が作用する場合には，次式により換算 曲げモーメント $M_{e q}$ を求め, 式 ( 9 )の $M$ に代入するも のとする゙'.

$$
\begin{aligned}
& M_{e q}=M C_{m} \ldots \ldots \ldots \ldots . . . .4 \\
& C_{m}=0.6+0.4 x \geqq 0.4
\end{aligned}
$$

ここで，M は絶対值が大きい方の端モーメントで正と し, $x$ は部材に半波長の変形が生ずる端モ一メントの場 合を正とする. 式(10)は応力照査のための式で, 道路橋 示方書と同じ考えで求めたものである.この式は不等曲 げモーメントが作用する部材に対してのみ必要な式であ る.

低減係数 $Q$ は短柱強度 (式 ( 3 )) 加求められたも のであるが $R$ を求める際には簡単化のため, 座屈係数 を $4 n_{f}^{2}$ または $4 n_{w}^{2}$ としている. 上述の設計式は $Q=1.0$ のとき（または式( 4 )より $R \leqq 0.444$ のとき) 道路橋示 方書の局部座屈を考えない照査式に一致する.

式( 9$),(10)$ の相関式を $x=1.0 ， 0.0 ， 1.0$ について 求めたものを Fig.7に示す.ただし，断面はフランジ, ウェブに等数のリブをもつ正方形箱形で, 材料は SS 41 , 細長比は 80 , 低減係数は $0.8\left(R=R_{f}=R_{w}=0.815\right)$ の 等断面柱を考えている. 設計では, 式( 9 )または(10)の 曲線のうち, 下方（原点寄り）にある曲線が支配曲線之 なる，図より， $x=0.0$ または -1.0 の場合には，かな りの部分が式(10)の応力照查で設計が支配されることに なる.

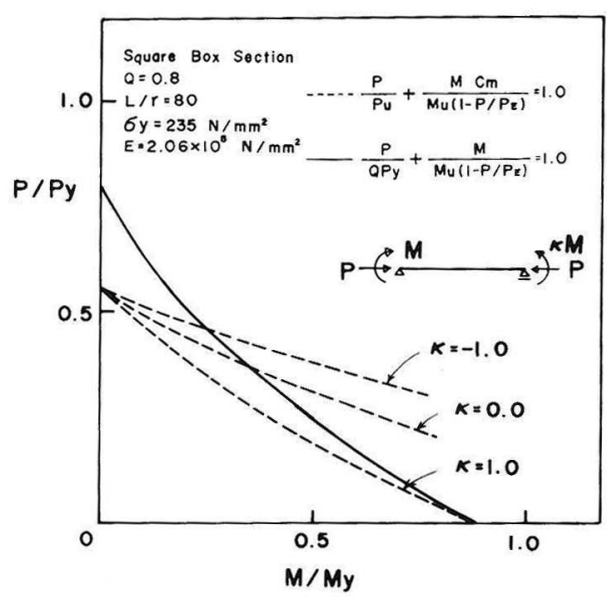

Fig. 7 Interaction Equations.

\section{5. 結言}

SM 58 材よりなる縦りブとダイヤフラムで補剛され た箱形断面偏心圧縮柱の局部座屈と全体座屈の連成強度 に関する実験結果について述べ, 強度の簡易推定法およ びそれに基づく設計公式の提案を行った．前報4）で提 
案した無補剛箱形断面圧縮部材の強度の簡易推定法と同 様,ここで提案した推定式は工学的に十分な精度で補剛 箱形断面圧縮部材の強度を推定することがわかった.

本研究は北港連絡橋主塔の設計に関する大阪市から名 古屋大学への委託研究の一部 ${ }^{81}$ として行われたものであ る. 実験に際しては名古屋大学の水野英一助手, 大谷恭 弘氏 (現·Purdue 大学院), 溝口博孝氏（現・横河橋 梁製作所), 土屋信洋氏（現・清水建設）および永田 健氏（現・建設省）の協力を得た.

6. 付 録

\section{（1）補剛断面の等価座屈係数 $k_{e q}$}

フランジ幅 $b$, ウェブ幅 $d$, フランジ板厚 $t$, ウェブ 板厚 $w$, フランジのサブパネル数 $n_{f}$, ウェブのサブパ ネル数 $n_{w}$ の等間隔補剛箱形断面を考える.ただし，補 剛材断面はフランジ，ウェブ板内で同一とする.このと き, 等価座屈係数 $k_{e q}$ は次式で与えられる ${ }^{4), 8}$.

$$
\begin{gathered}
k_{e q}=\left\{2 n_{f} \frac{1+\alpha \beta \cdot \Delta}{1+\alpha^{2} \Delta \cdot n_{f} / n_{w}}\right\}^{2} . \\
\text { ここに, } \alpha=d / b, \beta=w / t, \\
\Delta=\frac{1+\left(n_{w}-1\right) \delta_{w}}{1+\left(n_{f}-1\right) \delta_{f}} \\
\delta_{f}=A_{s f} / b t \\
\delta_{w}=A_{s w} / d w
\end{gathered}
$$

で, $A_{s s}$ はフランジ補剛材 1 本の断面積, $A_{s w}$ はウェブ 補剛材 1 本の断面積である. 式 $(A \cdot 1)$ の誘導は文献 8) に与えられている.

\section{（2）偏心圧縮柱の強度の推定法}

文献 4)，5）で述べた手法を補剛断面柱に拡張した方 法について述べる。この方法は短柱の強度をもとに長柱 の強度を推定しようとするものである. 問題を一般化す るため，付録( 1 )で述べたような断面を考える.

中心軸圧縮柱の場合には次のように強度を推定する. 短柱の強度として式( 3 )を用い,

$$
Q=1.24-0.54 R
$$

とおき, 局部座屈を考えないで求めた柱の強度式（本論 文の場合には SSRC No. 2 曲線 ${ }^{9}$ あるいは道路橋示方書 の基本耐荷力式 $\left.{ }^{3 \prime}\right)$ の降伏応力 $\sigma_{y}$ を $Q \bar{\sigma}_{y}$ に置き換えた 式をもって局部座屈を生じた部材の強度を推定する.
等偏心圧縮柱の場合には次の相関式

$$
\frac{P}{P_{u}}+\frac{P \cdot e}{M_{u}\left(1-P / P_{E}\right)}=1.0
$$

を用いる。ここに， $P_{u}$ は上述の手法によって求めた局 部座屈を考えた中心軸圧縮柱の強度, $P_{E}$ は才イラ一座 屈荷重, $M_{u}$ は次式より求められるフランジの局部座屈 を考えた降伏曲げモーメント（文献 5 ) の式 A.17に対 応する）である。

$$
\frac{M_{u}}{M_{y}}=\frac{(2+3 / \alpha \beta)\left(1.24-0.54 R_{f}\right)+2+\alpha \beta}{4+\alpha \beta+3 / \alpha \beta} \leqq 1.0
$$

$$
M_{y}=W \bar{\sigma}_{y}
$$

ここに，W=座屈軸に関する弾性断面係数である。た だし， $M_{\boldsymbol{u}}$ を求めるときには, 簡単化のため補剛材の断 面 2 次モーメントを無視している.

\section{参考 文 献}

1）本州四国連絡橋公団：本州四国連絡橋 -上部構造設計基 準・同解説, 1977 年 8 月.

2) Watanabe, E., Usami, T. and Hasegawa, A. : Strength and Design of Steel Stiffened Plates-A Literature Review of Japanese Contributions, Proc. US-Japan Seminar on Inelastic Instability of Steel Structures and Structural Elements, Tokyo, May, 1981.

3）日本道路協会：道路橋示方書・同解説， 1980 年 2 月,

4）宇佐美勉：福本唀士：鋼圧縮部材の連成座屈強度実験之 有効幅理論による解析, 土木学会論文報告集, 第 326 号, pp. $41 \sim 50,1982$ 年 10 月.

5）宇佐美勉・福本唀士・青木徹彦：溶接箱形断面柱の局部 座屈と全体座屈の連成強度に関する実験的研究, 土木学 会論文報告集, 第 308 号, pp. $47 \sim 58,1981$ 年 4 月.

6) Usami, T. : Postbuckling of Plates in Compression and Bending, Journal of Structural Division, Proc. ASCE, No. ST 3, Vol. 108, pp. 591 609, March, 1982.

7）青木徹彦・福本唀士：鋼材の座屈強度のばらつきにおよ ぼす残留応力分布の影響について, 土木学会論文報告集, 第 201 号, pp. $31 \sim 41,1972$ 年 5 月.

8）福本唀士・宇佐美勉・伊藤義人：北港連絡橋の主塔の強 度に関する基礎的研究, 名大土木研究報告 No. 8201, 名 古屋大学工学部土木工学科, 1982 年 9 月.

9) Johnston, B. G. (ed. ) : Guide to Stability Design Criteria for Metal Structures, 3rd. ed., John Wiley \& Sons, 1976.

(1983.10.28 - 受付) 